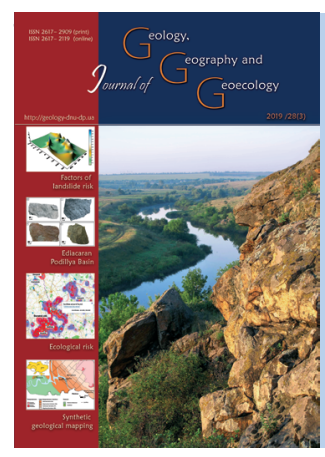

Journal of Geology.

ISSN 2617-2909 (print)

ISSN 2617-2119 (online)

Geography and

Geoecology

Journ.Geol.Geograph.

Geology,

28(3), 417-431.

Journal home page: geology-dnu-dp.ua

doi: $10.15421 / 111939$

Y. I. Gritsan, O. M. Kunakh, J. J. Dubinina, V. I. Kotsun, Y. I. Tkalich

Journ. Geol. Geograph. Geoecology, 28(3), 417-431.

\title{
The catena aspect of the landscape diversity of the «Dnipro-Orilsky» natural reserve
}

\author{
Yuriy I. Gritsan ${ }^{1}$, Olga M. Kunakh², Julia J. Dubinina ${ }^{3}$, Vadim I. Kotsun ${ }^{1}$, Yuriy I. Tkalich ${ }^{1}$ \\ ${ }^{1}$ Dnipro State Agrarian and Economic University, Dnipro,Ukraine, gritsan@i.ua \\ ${ }^{2}$ Oles Gonchar Dnipro National University, Dnipro,Ukraine, kunah_olga@ukr.net \\ ${ }^{3}$ Melitopol Institute of Ecology and Social Technologies of the Open International University of Human Development \\ «Ukraine», Melitopol, Ukraine.dubinina4884@ukr.net
}

Received: 26.03 .2019

Received in revised form: 24.04.2019

Accepted: 21.06.2019 Abstract. In the present investigation catena approaches to assess the landscape diversity
of the "Dnipro-Orilsky" natural reserve was developed. Catena which lies in the reserve
embraces flood and arena biogeocoenoses. The research was performed during the $2014-$
2018. The two profiles were made at the "Dnipro-Orilsky" natural reserve within which
main geomorphological landscape elements are presented. There are 29 sampling polygons within these $p$ rofiles. The soil profile description, vegetation investigation, soil and soil animals quantitative assessment was carried out in each of them. In this publication we presented the results of sampling polygons 1-4, 25 and 26. The profile 1 best reflects the traditional view of catena: it goes from the highest places of the sand terrace (arena) to the lowest place (floodplain). But relief diversity is increased by the availability of small river Protich. It floodplain provides an alternative transit and accumulation gradient. It should be noted that the main part of the main slope profile does not fully meet the transit regime, as compiled by sandy soils, which are characterized by high filtration capacity. Therefore, the slope profile position is largely corresponded to eluvial regimes. The accumulative part of the profile which corresponds to the floodplain of Dnipro river is significantly influenced by impact of the flood factor than the accumulative part of the profile which corresponds to the floodplain of Protich river. The soils within floodplain of Protich river have more quantity of clay. Clay soils are characterized by capillary properties, as soil salinization is common in the floodplain of Protich river. Alternative profile 2 includes Orlov valley. This element of the landscape is accumulative, but not affected by flood factor. In the biogeocenotic context catena sampling points were considered as being composed of pedocatena, phytocatena and zoocatena. The biogeocenotic approach is the chain that connects the landscape structure, the diversity of soil cover, and diversities of the plant and animal communities. The functional, spatial and temporal properties of ecosystems in landscape context can be expressed by catena. The biogeocoenosis concept is a basis for integration of the pedocatena, phytocatena and zoocatena. Catena approach is the framework for a monitoring system landscape diversity both at the level of individual component biogeocoenosis (edaphotop, phytocenosis, and zoocenosis) and biogeocoenosis level in terms of its horizontal and vertical structure and at the landscape level as a whole interconnected system. The traditional idea of catena as a set of eluvial, transit and accumulative positions in a complex and diverse landscape is not able to cover the most important environmental gradients modes. The complexity of the landscape is due to relief diversity and the effects of anthropogenic transformation biogeocenotic cover. Catena therefore can be seen as a multilevel hierarchical system of the biogeocenotic polygons needed to consider the diversity of physiographic conditions and anthropogenic gradients.

Key words: catena, landscape, soil, natural reserve, diversity

\section{Катений аспект ландшафтного різноманіття природного заповідника «Дніпровсько- Орільський»}

\author{
Ю.І. Грицан ${ }^{1}$, О.М.Кухан ${ }^{2}$ Ю.Ю.Дубініна ${ }^{3}$, В.І.Коцун ${ }^{1}$, Ю.І. Ткаліч ${ }^{1}$
}

${ }^{1}$ Дніпровський державний аграрно-економічний університет, Дніпро, Украӥна, gritsan@i.uа
${ }^{2}$ Дніпровський національний університет імені Олеся Гончара, Дніпро, Украӥна, kunah_olga@ukr.net
${ }^{3}$ Мелітопольський інститут екології та соиіальних технологій відкритого Міжнародного університету
гуманітарного розвитку «Украӥна», Мелітополь, Украӥна, dubinina4884@ukr.net

Анотація. У дослідженні був розроблений катений підхід для оцінки ландшафтного різноманіття природного заповіднику «Дніпровсько-Орільський». Катена, яка знаходиться у заповіднику, охоплює заплавні та арені біогеоценози. Дослідження про- 
водилося протягом 2014-2018 pр. У межах природного заповіднику «Дніпровсько-Орільський» закладені два профілі, у межах яких представлені основні геоморфологічні елементи ландшафту. Уздовж профілів розміщені 29 експериментальних полігонів. Описи грунтового профілю, вивчення рослинності, грунтів і кількісна оцінка грунтових тварин були проведені в кожному з цих полігонів. У цій публікації ми представили результати по полігонам 1-4, 25 і 26. Профіль 1 найкраще відображає традиційне уявлення про катену: він йде з найвищих місць на боровій терасі (арена) до найнижчого місця (заплава р. Дніпро). Але різноманітність рельєфу збільшується за рахунок наявності малої річки Протіч. Ї̈̈ заплава забезпечує альтернативний транзитний і акумулятивний градієнти. Основна частина головного профілю схилу не у повній мірі відповідає транзитного режиму, так як він складений з піщаних грунтів, які характеризуються високою фільтруючою здатністю. Таким чином, положення профілю схилу в значній мірі відповідає елювіальний режимам. Акумулятивна частина профілю, яка відповідає заплаві річки Дніпра, в значній мірі залежить від впливу фактора повені, ніж акумулятивна частина профілю, яка відповідає заплаві річки Протіч. Грунти у межах заплави річки Протіч мають більший вміст глини. Глинисті грунти характеризуються капілярними властивостями, тому і засолення грунту значно більш поширене у заплаві річки Протіч. Альтернативний профіль 2 включає в себе Орлову балку. Цей елемент ландшафту є накопичувальним, але не зазанє впливу фактору повені. У біогеоценотичному контексті катену розглядають як сукупність точок відбору проб, які складаються з педокатени, фітокатени і зоокатени. Біогеоценотичний підхід є ланцюгом, що з’єднує структуру ландшафту, різноманітність грунтового покриву і різноманітність рослинних і тваринних угруповань. Функціональні, просторові і часові властивості екосистем в ландшафтному контексті можуть бути виражені за допомогою катени. Біогеоценотична концепція є основою для інтеграції педокатени, фітокатени i зоокатени. Катений підхід є основою для системи моніторингу ландшафтного різноманіття як на рівні окремих компонентів біогеоценозу (едафотоп, фітоценоз та зооценоз), на біогеоценотичному рівні в аспекті його горизонтальної та вертикальної структури та і на ландшафтному рівні у якості цілістної системи взаємопов'язаних частин. Традиційне уявлення про катену як набір елювіальних, транзитних та акумулятивних позицій не може повною мірою відобразити найбільш важливі градієнти екологічних режимів. Складність ландшафту виникає внаслідок різноманіття рельєфу та ефектів антропогенної трансформації біогеоценотичного покриву. Тому катена може розглядатися як багаторівнева ієрархічна система біогеоценотичних полігонів, яка необхідна для характеристики різноманіття фізико-географічних умови і антропогенних градієнтів.

Ключові слова: катена, ландщафт, трунт, природний заповідник, різноманіття

Introduction. The diversity of the landscape plays an important role in shaping the diversity and stability of living organisms communities (Zhukov et al., 2015). Catena is the elementary structure unit of the landscape (Bahnov et al., 1988). The term «catena» was originally proposed for soil layer of the biogeocenotic cover and in such a narrow scope is traditionally used to date (Milne, 1935; Urusevskaya, 1990). Within the landscape the series of horology units from the top of the watercourse to the watershed is connected to a number of soil types arrayed along a relief slope. The differences between soil types within catena are related to the difference of altitude and slope affecting on drainage (Milne, 1935; Zaugolnova, 2010). These kinds of catena are called «soil catena» or «pedocatena» (Zaugolnova, 2010). The methodology of the soil catena approach was developed by T. Bashnell (1942), F. Hole (1953), D. Yaalon (1971), A. Gerrard (1984). The catenas are distinguished by the following features: a) according their zone-climatic properties; b) according the composition of the soil components; c) depending on the relief genetic type; d) the main differentiating factors in soil catena - features of lithology, erosion role, hydrological regime, nature of surface water redistribution (Fridland, 1972; Karavaeva, 1982; Urusevskaya, 1990; Kozlovsky, 2003; Gennadiev \& Kasimov, 2004).

Catena allows you to fully express the natural spatial and temporal properties of ecosystems that characterize their diversity and dynamics (Diduh, 2008). Appropriate horological units in a vegetation cover are called "phytocatena" (Katenin, 1988; 418
Kholod, 1991; Zaugolnova, 2001). In forest science the similar approach is represented by consideration of the forest community series in different types of soil (Romanovsky, 2002). A. E. Katenin (1988) suggested to use the concept catena only in respect of uniform lithological structures. The idea of monolithic and hetorolithic geocatenas allows to use catena concept for relatively homogeneous and heterogeneous areas (Gennadiev \& Kasimov, 2004). Depending on this catenas found may be more simple or more complex in structure. The increasing complexity of the phytocatena structure occurs as more and more streams are taken in consideration as a result of increasing the catchment area (Zaugolnova, 2010). The geographical and geochemical systematic of catenas was designed, which includes such taxonomic units as a group, subgroup, category, type, subtype, family, class, genus and species (Gennadiev \& Kasimov, 2004).

The catena approach is most commonly used in practice of the soil animals study (Mordkovich et al., 1985; Zhukov et al., 2016). Catena is a geomorphological profile that runs from the highest place certain territory to the lowest. This profile is graduated in the context of individual factors (humidity, temperature, soil salinity, etc.) or a set of landscape conditions. Therefore, catena is a convenient model of the area through which you can evaluate the environmental preferences of the selected species along the gradient environment (Kaprus, 2011). The approaches were developed for the application of catena method to the study of the diversity of the soil animal communities within arena landscape of the Dnipro valley (within 
the "Dnipro-Orylskiy" natural reserve) by means of phytoindication assessment of the basic trends of variability of environmental conditions (Zhukov et al., 2016).

From a practical point of view, catena may be considered any arbitrarily chosen of the landscape slope or the whole slope, which is a set of habitats with regular changes in environmental conditions, which is due to the relief (Mordkovich et al., 1985). There is no matter inflow (other than precipitation) at the top of a catena and there is no matter outflow at the bottom. The starting element of catena is an eluvial topographic position, and the terminal is an accumulative topographic position. Among them are transit positions. Standard catena consists from five positions: eluvial, 1st, 2nd, and 3rd transit and accumulative. The soil is responsive to changes in topography. The increase down the slope total wetting of soils and their quality determines the change in plant and animal communities (Mazey \& Embulaeva, 2015).

Catena elements can be combined into complexes of a higher hierarchical level. The some links in the chain (catena) which are presented by specific habitats or plant communities, combined in mesocombinations and the last - in macrocombinations. The mesocombinations are also interpreted as ecomeres and can be characterized using phytoindication approach (Didukh et al., 2015).

Diversity is the basis of functional stability of the biogeocenosis (Zhukov \& Gubanova, 2015). Soils represent an important aspect of biological diversity and form the aim and conditions of its preservation. Therefore, the study of soil diversity of the «DniproOrilsky» natural reserve is an important and urgent problem. Of particular importance is the study of arena and floodplain soils, characterized by a large diversity of their soil forming process complexity. The variation of the physical properties of the soil has a significant ecological value (Karpachevsky, 2005). The existence of the soil ecomorphes was proved based on the research of spatial-temporal dynamics of soil mechanical impedance (Zhukov \& Zadorozhnaya, 2016). Other soil physical properties such as electrical conductivity, density, and wetness are also important genetic and ecological properties (Karpachevskij, 2005; Zhukov et al., 2011; 2012; Zhukov et al., 2016).

The aim of the present investigation is to develop catena approaches to assess the landscape diversity of the «Dnipro-Orilsky» natural reserve.

Materials and methods. Relief of the «DniproOrilsky» nature reserve is presented by the forms of the alluvial or aeolian origin of the Dnipro lowland. There are three terraces within the area of the natural reserve. The well-developed floodplain terrace has the lowest position which is rugged in different directions by numerous channels, dotted with lakes and marshes, stretching along the Dnipro by a belt $16 \mathrm{~km}$. In the widest part, Taromske ledge, floodplain terrace is $2 \mathrm{~km}$ and in the narrowest part in the Nicholas ledge is $1 \mathrm{~km}$. The floodplain soils are represented by a layered modern alluvium. Its lower layers are fluvial facies, formed when water levels decline due to settling of sediment deformation during routine bed. The floodplain is covered with numerous lakes, some of which turned into swamps, and rugged by a chain of the winding or sickle oxbow lakes and channels (Manyuk, 2005).

Catena which lies in the reserve embraces flood and arena biogeocoenoses (Fig. 1). The research was performed during the 2014-2018. 29 sampling polygons were made. The soil profile description, vegetation investigation, soil and soil animals quantitative assessment was carried out in each of them. In this publication we presented the results of sampling polygons $1-4,25$ and 26 .

The electrical conductivity of the soil was measured in every $5 \mathrm{~cm}$ from the soil surface with 3 times frequency. Measuring the electrical conductivity of the soil (apparent soil electrical conductivity - $\mathrm{EC}_{\mathrm{a}}$ ) ws made by using sensor HI 76305 (Hanna Instruments, Woodsocket, RI) showed a significant performance in conducting soil and environmental studies (Pennisi, van Iersel, 2002; Scoggins, van Iersel, 2006; Smagin, 2012; Zhukov et al., 2011; 2012; Zhukov et al., 2016).

The measurements of soil mechanical impedance were made in the field using hand penetrometer Eijkelkamp with an interval of $5 \mathrm{~cm}$ (Zhukov, 2015). The average error of the results of the measurement device is $\pm 8 \%$. Measurements were performed by the cone with the size of cross section of $2 \mathrm{~cm}^{2}$. The measurements of soil mechanical impedance were made with 3 times frequency within each soil profile. The bulk density of the soil was determined using the method of Kaczynski, and humidity was determined by weight method (Vadunina, Korchagina, 1986; Zhukov et al., 2015). Morphological Soil profile description was performed according to Rozanov (2004). The expert method was used for the type profiles formalized description of the derived empirical data. Graphical display of the soil profiles completed in the program of Strater (C) v. 4 (Golden Software, LLC).

Results and discussion. The two profiles were made at the «Dnipro-Orilsky» natural reserve within which main geomorphological landscape elements are presented (Fig. 1). The profile 1 best reflects the traditional view of catena: it goes from the highest places 


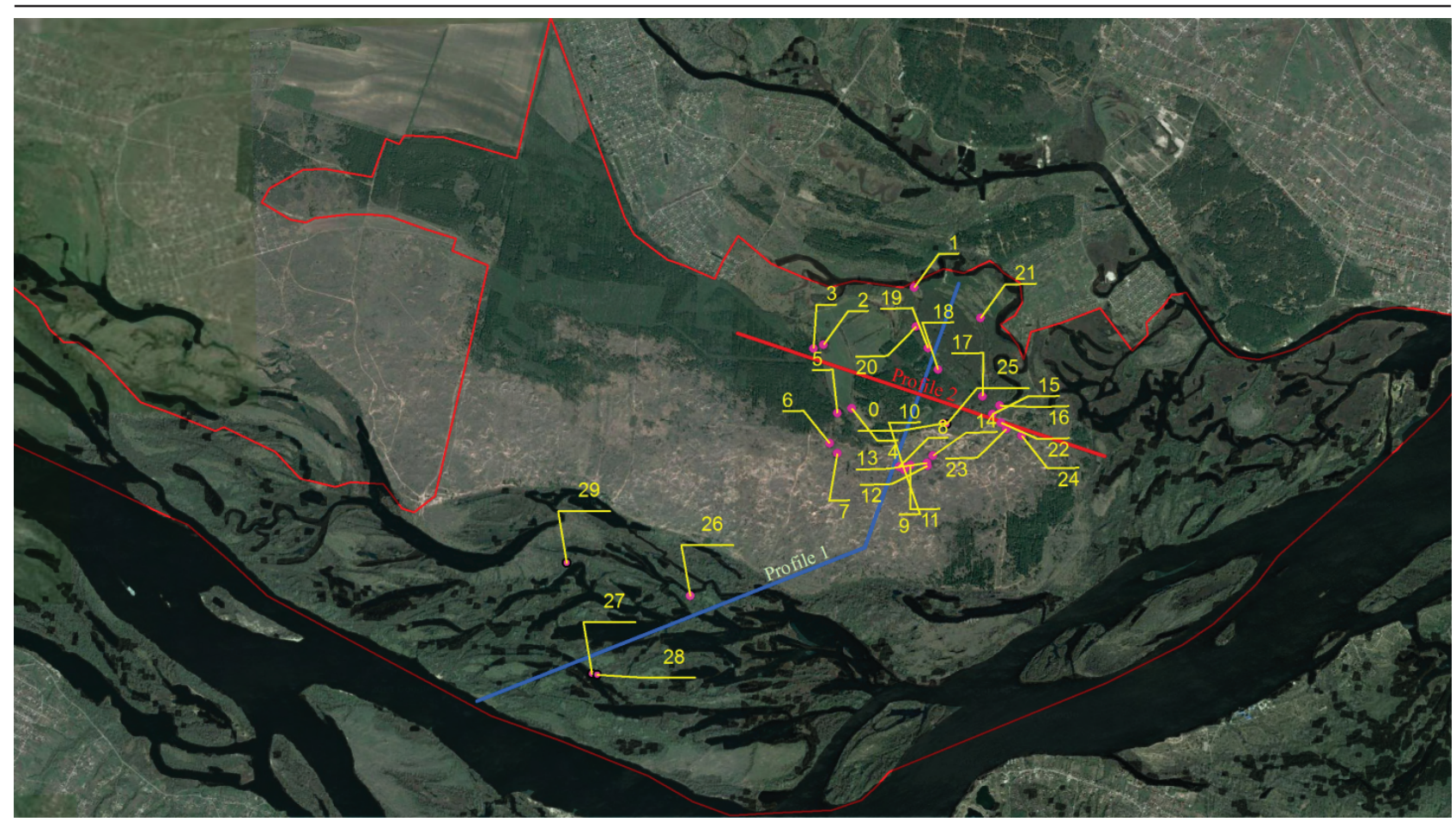

Fig. 1. The placing of biogeocenotic plots within the "Dnipro-Orilsky" natural reserve: sandy terrace: 1 - meadow, floodplain of Protich river; 2 - oak forest, Orlov valley; 3 - artificial pine plantations, the slope of northern exposure of the Orlov valley; 4 meadow, Orlov valley; 5 - artificial pine plantations, sand hill top; 6 - psamophytic steppe, dune gate (interdune bottom); 7 - psamophytic steppe, the top of the hill; 8 - psamophytic steppe, the top of the hill; 9 - psamophytic steppe, dune gate; 10 - Tatarian maple bush, hillside; 11 - Tatarian maple bush, dune gate; 12 - Tatarian maple bush, hillside; 13 - psamophytic steppe, the top of the hill; 14 - psamophytic steppe, dune gate; 15 - oak forest, floodplain of Protich river; 16 - wooded bog, floodplain of Protich river; 17 shrub bog, floodplain of Protich river; 18 - artificial pine plantations, slope arena which is adjacent to the floodplain of Protich river; 19 - oak forest, the slope of the arena, which is adjacent to the floodplain of Protich river; 20 - swamp, dune gate; 21 - meadow, floodplain of Protich river; 22 - psamophytic steppe, the top of the hill; 23 - psamophytic steppe, dune gate; 24 - Tatarian maple bush, the top of the hill; 25 - white poplar forest, the floodplain of Protich river. The floodplain of Dnipro river: 26 - oak forest, terrace near flood plain; 27 - oak forest, riverine floodplain; 28 - oak forest, riverine floodplain, Graduation to the central floodplain; 29 - oak forest, central floodplain (image taken from the satellite DG, source - maps.ovi.com)

of the sand terrace (arena) to the lowest place (floodplain). But relief diversity is increased by the availability of small rivers Protich (Table. 1). It floodplain provides an alternative transit and accumulation gradient. It should be noted that the main part of the main slope profile does not fully meet the transit regime, as compiled by sandy soils, which are characterized by high filtration capacity. Therefore, the slope profile position is largely corresponded to eluvial regimes.

The accumulative part of the profile which corresponds to the floodplain of Dnipro river is significantly influenced by impact of the flood factor than the accumulative part of the profile which corresponds to the floodplain of Protich river. The soils within floodplain of Protich river have more quantity of clay. Clay soils are characterized by capillary properties, as soil salinization is common in the floodplain of Protich river.

Alternative profile 2 includes Orlov valley. This element of the landscape is accumulative, but not affected by flood factor.

In the biogeocenotic context catena sampling points were considered as being composed of pedocatena, phytocatena and zoocatena. The most common characteristic biogeocenosis within catena investigated are presented further.

Sampling polygon № 1. The vegetation of meadow included a total of 29 species of vascular plants, among which are dominated by Poa pratensis (L), Calamagrostis epigeios (L) Roth. Inula britannica (L) is a subdominant. The total projective cover of herbaceous species is 100\% (Gudym \& Ganzha, 2016). For identification of plant communities, within which research was undertaken, we give it a syntaxonomy characteristic.

Syntaxonomy of the plant community:

Class Molinio-Arrhenatheretea Tx., 1937

Ordo Agrostietalia stoloniferae Oberd. in Oberd. et al., 1967

Union Festucion pratensis Sipajlova et al., 1985

All. Poetum pratensis Steppeanović, 1999

The herpetobiont invertebrates community included a total of 80 species representing 28 families 

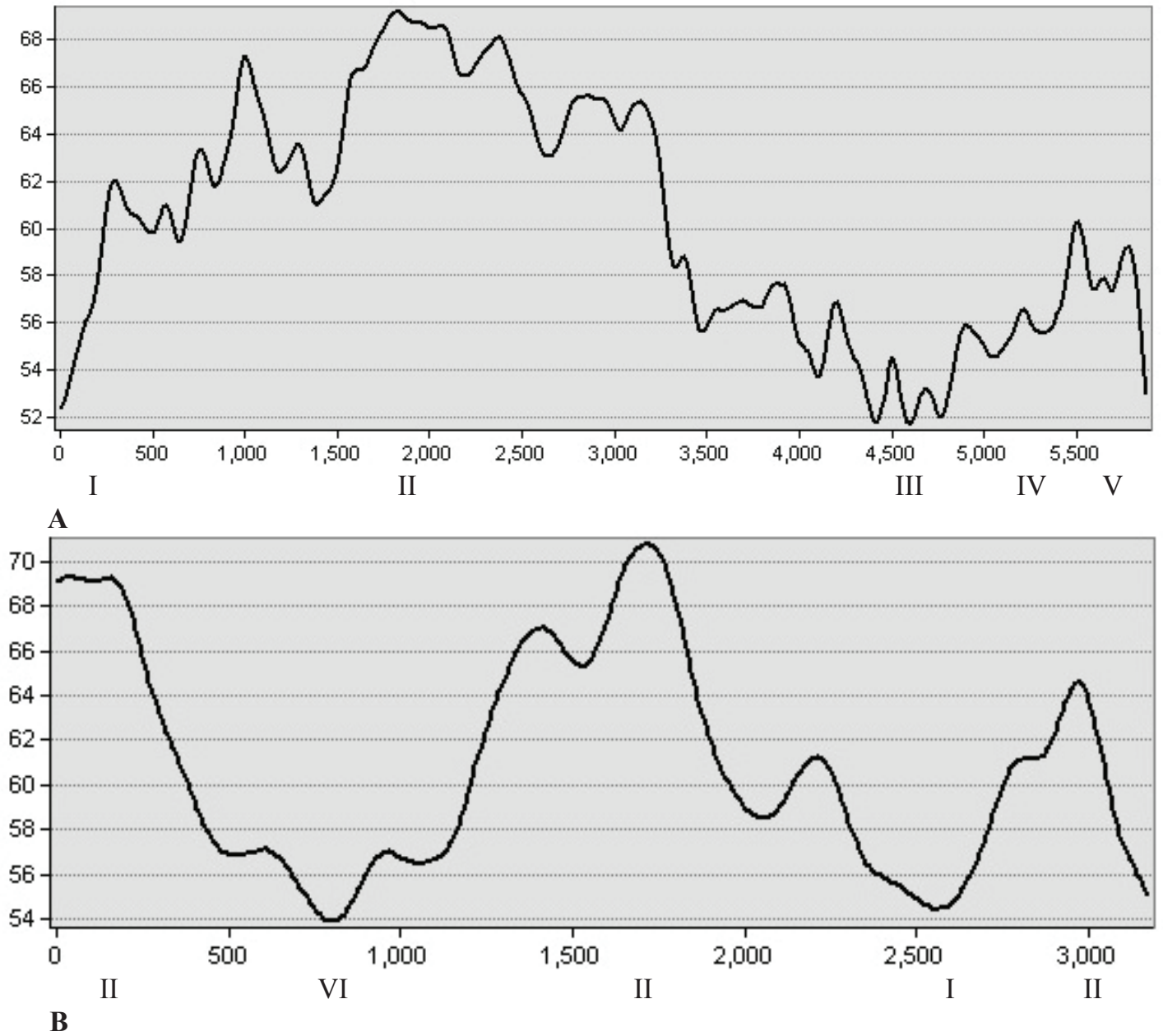

Fig. 2. Geomorphological profiles, along which catena plots are placed: A - geomorphological profile 1, B - geomorphological profile 2: I - floodplain of Protich river; II - sandy terrace; III - terrace near flood plain of Dnipro river; IV - central floodplain of Dnipro river; V - riverine floodplain of Dnipro river; VI - Orlova valley

and 11 orders and 6 classes from two phylum (arthropods and molluses) at the sampling polygon (Zhukov et al., 2017). Carabus excellens and Taphoxenus gigas are included in the Red Book of Dnepropetrovsk region (Sumarokov et al., 2018).

\section{Soil profile description}

The description was made in 3 October 2018. The soil section was located in the beach of the Protich river within the "Dnipro-Orylskiy" natural reserve (Fig. 3, A). The vegetation is presented by meadow. The soil surface is relatively smooth. There is a litter cover with depth of 3-4 $\mathrm{cm}$ and with projective cover $90-100 \%$. The parent material is alluvial sand. The groundwater level is at a depth of $200 \mathrm{~cm}$. There are no the visible soil neoformation, carbonate debris, accumulation of salts. The soil consistency is dense. The genetic type of the profile is humus-gley. An intense carbonate effervescence after dilute hydrochloric acid treatment was occurred from 31 to $90 \mathrm{~cm}$.

$\mathbf{H}_{0}(2-0 \mathrm{~cm})-$ organogenic horizon, litter with projected cover $70-90 \%$.

$\mathbf{H}_{\mathbf{d}}(0-7 \mathrm{~cm})$ - the upper humus-accumulative soddy horizon. The quantity of roots is common. Dark grey. Moderately moist. Light loam. Loose. Structureless, rare aggregates are unstable, some aggregates are bonded by clusters of grasses roots. Cracks are missing. The distinctness with next horizon is abrupt, may be detected on the basis of the clear roots content decrease and changes of the consistency.

Hk $(7-48 \mathrm{~cm})$ - upper humus-accumulative carbonate. Dark grey. Dense. Moist. Light loam. Roots are absent. Cracks are missing. The distinctness with next horizon is gradual, may be detected on the basis of the color.

HPk $(48-75 \mathrm{~cm})$ - transition carbonate. Light grey, gradually brightens with depth. Dense. Moist. Light loam. Roots are absent. The distinctness with next horizon is gradual, may be detected on the basis of the color.

Ph1k $(75-113 \mathrm{~cm})$ - the first lower transition carbonate horizon. Light gray. Moderately moist. Consistence is compact. Light loam, there are no cracks. Humus spots of irregular shape with a diameter of $15-20 \mathrm{~cm}$ are presented. The distinctness with next horizon is gradual, may be detected on the basis of the color. 
Ph2 (113-136 см) - the second lower transition. Gray with humus spots. Consistence is compact. Light loam. Moderately moist. The distinctness with next horizon is clear, may be detected on the basis of the color.

Ph3gl (136-152 cm) - the third lower transition gleyey. Blue-gray. Clay sand. There are no cracks. Very moist. Consistence is compact. The distinctness with next horizon is clear, may be detected on the basis of the color.

P1G (152-171 cm) - gley parent material. Dark blue-gray clay sand with reddish spots. Consistence is soft. The distinctness with next horizon is gradual, may be detected on the basis of the texture changes.

P2G (171-200 cm) - gley parent material. Dark blue-gray sand with reddish spots. Consistence is soft.

The working definition of soil: sod carbonate gley soil (Calcic Gleysols (Humic)).

Sampling polygon № 2. The vegetation of oak forest included a total of 48 species of vascular plants. The tree stand are dominated by Quercus robur L., Pyrus communis L.. The shrub layer are dominated

Table 1. Elements of biogeocenotic catena

\begin{tabular}{|c|c|c|c|c|}
\hline $\mathrm{N}$ & Biogeoceonosis & $\begin{array}{l}\text { Element of the } \\
\text { catena }\end{array}$ & Flood regime & Topographic position \\
\hline \multicolumn{5}{|c|}{ Sandy terrace } \\
\hline 1 & Meadow & Accumulative & Short term flooding & Floodplain of Protich river \\
\hline 2 & Oak forest & Transitional & Without flooding & Orlov valley \\
\hline 3 & Artificial pine plantations & Transitional & Without flooding & $\begin{array}{l}\text { The slope of northern exposure of the } \\
\text { Orlov valley }\end{array}$ \\
\hline 4 & Meadow & Accumulative & Without flooding & Orlov valley \\
\hline 5 & Artificial pine plantations & Eluvial & Without flooding & Sand hill top \\
\hline 6 & Psamophytic steppepe & Accumulative & Without flooding & Dune gate \\
\hline 7 & Psamophytic steppepe & Eluvial & Without flooding & Sand hill top \\
\hline 8 & Psamophytic steppepe & Eluvial & Without flooding & Sand hill top \\
\hline 9 & Psamophytic steppepe & Accumulative & Without flooding & Dune gate \\
\hline 10 & Tatarian maple bush & Transitional & Without flooding & Hillside \\
\hline 11 & Tatarian maple bush & Accumulative & Without flooding & Dune gate \\
\hline 12 & Tatarian maple bush & Transitional & Without flooding & Hillside \\
\hline 13 & Psamophytic steppepe & Eluvial & Without flooding & Sand hill top \\
\hline 14 & Psamophytic steppepe & Accumulative & Without flooding & Dune gate \\
\hline 15 & Oak forest & Accumulative & Short term flooding & Floodplain of Protich river \\
\hline 16 & Wooded bog & Accumulative & Short term flooding & Floodplain of Protich river \\
\hline 17 & Shrub bog & Accumulative & Short term flooding & Floodplain of Protich river \\
\hline 18 & Artificial pine plantations & Transitional & Without flooding & $\begin{array}{l}\text { The slope arena which is adjacent to } \\
\text { the floodplain of Protich river }\end{array}$ \\
\hline 19 & Oak forest & Transitional & Without flooding & $\begin{array}{l}\text { The slope arena which is adjacent to } \\
\text { the floodplain of Protich river }\end{array}$ \\
\hline 20 & Swamp & Accumulative & Without flooding & Dune gate \\
\hline 21 & Meadow & Accumulative & Short term flooding & Floodplain of Protich river \\
\hline 22 & Psamophytic steppepe & Eluvial & Without flooding & Sand hill top \\
\hline 23 & Psamophytic steppepe & Accumulative & Without flooding & Dune gate \\
\hline 24 & Tatarian maple bush & Eluvial & Without flooding & Sand hill top \\
\hline 25 & White poplar forest & Transitional & Short term flooding & Floodplain of Protich river \\
\hline \multicolumn{5}{|c|}{ The floodplain of Dnipro river } \\
\hline 26 & Oak forest & Accumulative & Moderate term flooding & Terrace near flood plain \\
\hline 27 & Oak forest & Accumulative & Moderate term flooding & Terrace near flood plain \\
\hline 28 & Oak forest & Accumulative & Moderate term flooding & Graduation to the central floodplain \\
\hline 29 & Oak forest & Accumulative & Moderate term flooding & Central floodplain \\
\hline
\end{tabular}




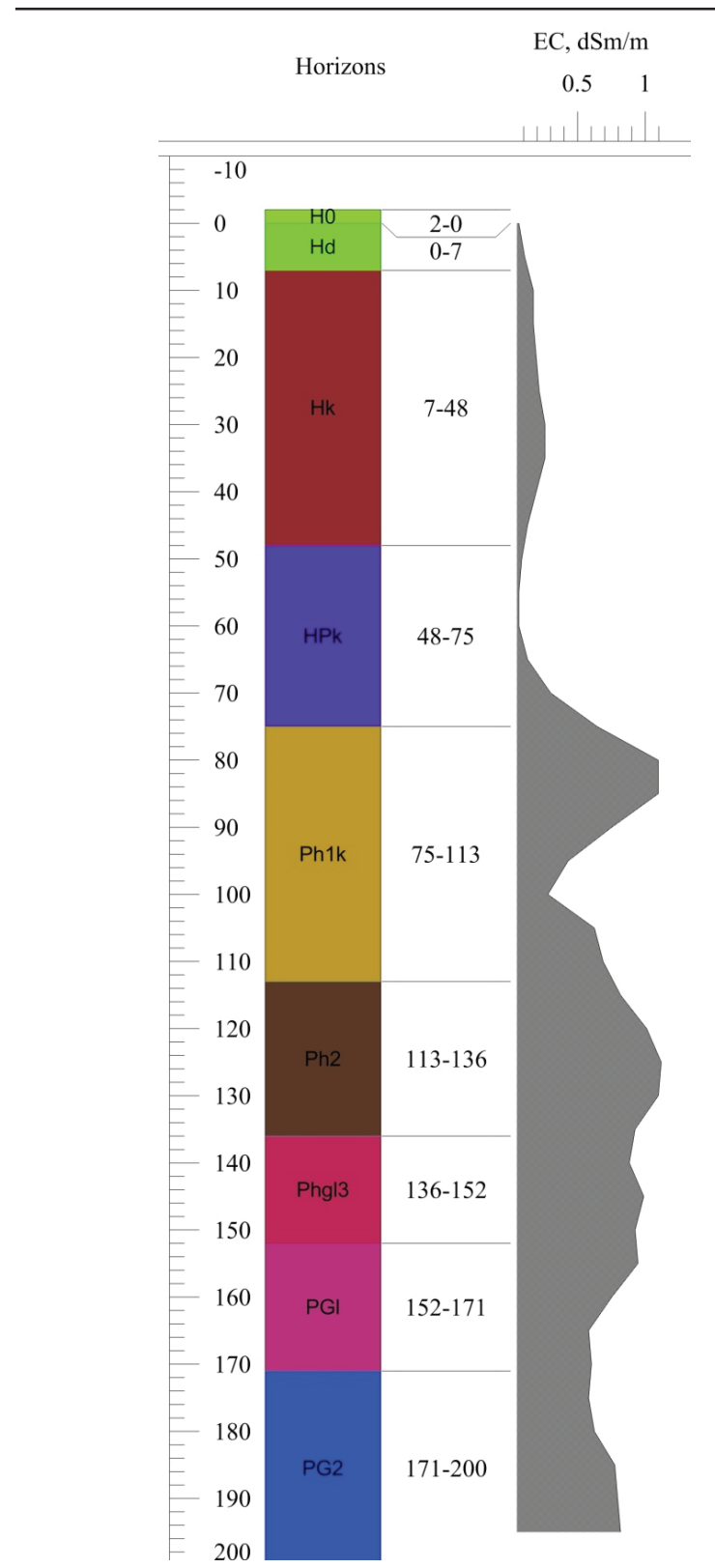

A
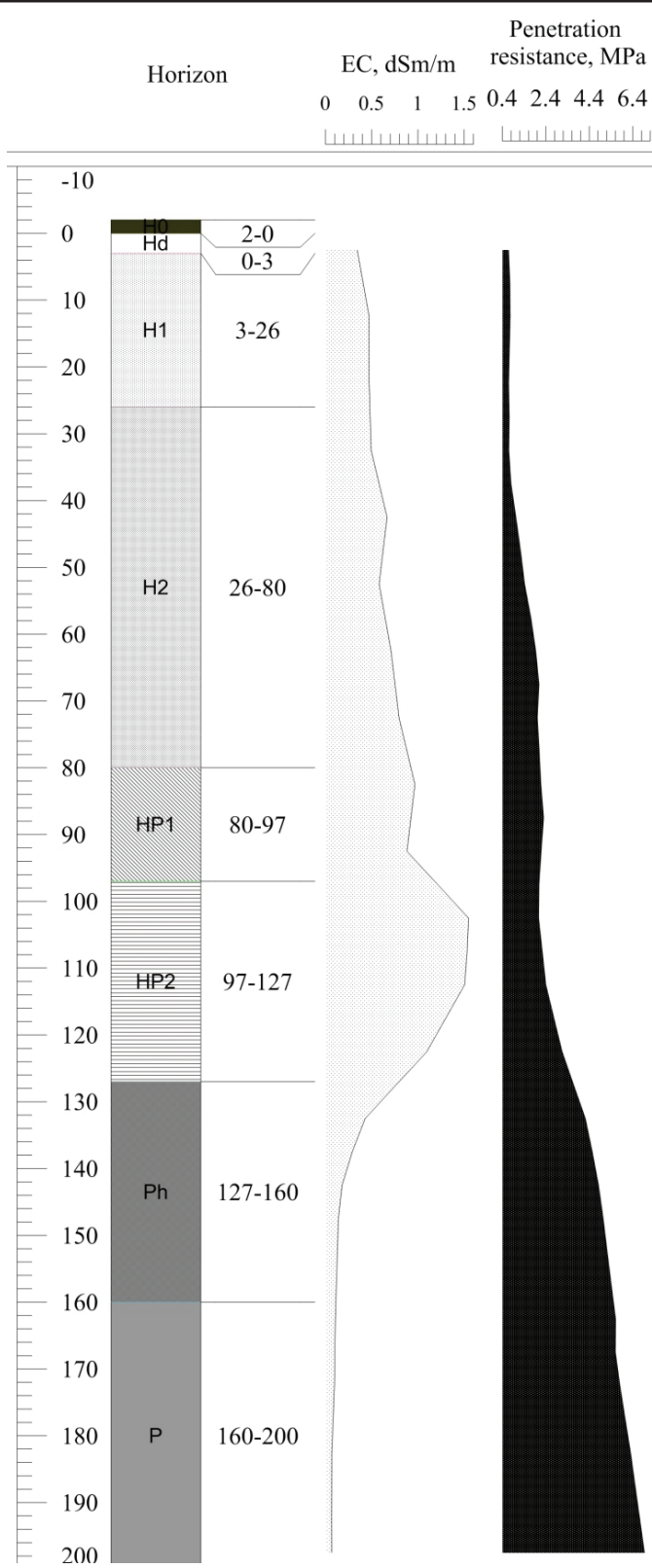

B

Fig. 3. The profile of sod-gley carbonate soil (Calcic Gleysols (Humic)) (A) and sod-forest chornozem-like deep carbonate soil (Phaeozems Arenic) (B)

Legend: $\mathrm{A}-\mathrm{H}_{0}$ - organogenic horizon, $\mathrm{H}_{\mathrm{d}}$ - the upper humus-accumulative soddy horizon, Hk - upper humus-accumulative carbonate horizon, $\mathrm{HPk}$ - transition carbonate, $\mathrm{Ph} 1 \mathrm{k}$ - the first lower transition carbonate horizon, $\mathrm{Ph} 2$ - the second lower transition horizon, Ph3gl - the third lower transition gleyey horizon, P1G - gley parent material, P2G - gley parent material; $\mathrm{B}-\mathrm{H}_{0}$ - organogenic, $\mathrm{H}_{\mathrm{d}}$ - upper humus-accumulative, soddy horizon, $\mathrm{H}_{1}-$ the first humus-accumulative, $\mathrm{H}_{2}$ - the second humus-accumulative, $\mathrm{HP}_{1}$ - the fist transition horizon, $\mathrm{HP}_{2}-$ the second transition horizon, $\mathrm{Ph}_{\mathrm{k}}$ - the lower transition carbonate horizon, $\mathrm{P}_{\mathrm{k}}-$ parent material.

by Acer tataricum L., Crataegus fallacina Klokov, Sambucus nigra L., the herbaceous layer are dominated by Galium aparine L ., Glechoma hederacea L., Urtica dioica L., Vincetoxicum rossicum (Kleop.) Barbar. The total projective cover of herbaceous species is $15-20 \%$ (Zhukov et al., 2018). For identification of plant communities, within which research was undertaken, we give it a syntaxonomy characteristic.
Class Querco-Fagetea Br.-Bl. et Vlieger in Vlieger 1937

Ordo Quercetalia pubescenti-petraeae Klika 1933

Union Aceri tatarici-Quercion Zolyomi 1957

All. Vincetoxico hirundinariae-Quercetum roboris Sokolova, 2011

The herpetobiont invertebrates community included a total of 66 species representing 24 families 
and 11 orders and 7 classes from tree phylum (annelida, arthropods and molluscs) at the sampling polygon (Zhukov et al., 2017). Carabus excellens is included in the Red Book of Dnepropetrovsk region (Sumarokov et al., 2018).

\section{Soil profile description}

The description was made in 11 September 2017. The soil section was located in the Orlova vallay within the "Dnipro-Orylskiy" natural reserve (Fig. 3 , B). The soil surface is relatively smooth. There is the litter consisted from leaves, not decayed, with a depth of $2-3 \mathrm{~cm}$, projective cover is $90-100 \%$. The fallen leaves are disintegrated well, the bottom layer of the litter is dust. The projective cover of the grass layer is $15-20 \%$. The parent material is alluvial sand. The groundwater level was not found. The depth of the roots of trees and shrubs up to $200 \mathrm{~cm}$. There are no the visible soil neoformation, carbonate debris, accumulation of salts. There are some traces of soil invertebrates activity. Evidence of the gleying were not found. Consistence is dense. The genetic profile type is humus differentiated. An intense carbonate effervescence after dilute hydrochloric acid treatment was occurred from $127 \mathrm{~cm}$.

$\mathbf{H}_{\mathbf{0}}(2-0 \mathrm{~cm})-$ organogenic, forest litter with projected cover $90-100 \%$.

$\mathbf{H}_{\mathbf{d}}(0-3 \mathrm{~cm})$ - upper humus-accumulative, soddy. Very dark gray (5Y 3/1). Dry. Clay sand. Consistence is friable. The soil is moderately or weakly bounded by root systems of herbaceous plants. Soil structure is very coarse, grain-dust. There are no ckraks. Animals pedoturbation is occurred. The distinctness with next horizon is abrupt, may be detected on the basis of the color and consistence.

$\mathbf{H}_{1}(3-26 \mathrm{~cm})-$ the first humus-accumulative. Dark gray (7.5YR 4/1). Moderately dry. Clay sand. Dense. There are some roots of shrubs. Structureless. The distinctness with next horizon is abrupt, may be detected on the basis of the color and consistence.

$\mathbf{H}_{2}(26-80 \mathrm{~cm})$ - the second humus-accumulative. Reddish gray (7.5R 5/1), becomes lighter with depth and reddish shade decreases. Slightly moist. Loamy sand. Consistence is compact. Structureless. There are some roots of shrubs. There are fragmentary inclusion of yellow sand grains. The distinctness with next horizon is graduated, may be detected on the basis of the color.

HP $_{1}(80-97 \mathrm{~cm})$ - the fist transition horizon. There are olive gray (5Y 5/2) or blue gray (5PB 5/1) vertically oriented oval spots $1-2 \mathrm{~cm}$ wide and 12.7 $\mathrm{cm}$ high on the grey background (2.5Y 6/1). Slightly moist. Consistence is compact. There are no roots. Loamy sand. There are no cracks. Structureless. The distinctness with next horizon is clear, may be detected on the basis of the color.

$\mathbf{H P}_{2}(97-127 \mathrm{~cm})$ - the second transition horizon. Grey-brown background (2.5Y 5/2) with vertical oval dark-gray spots $(\mathrm{N} 4 / 0)$ of the humus material width of $1 \mathrm{~cm}$, height $-3-4 \mathrm{~cm}$. Also, there are some roundspots of irregular shape with a diameter of $7.8 \mathrm{~cm}$, probably - burrows of soil mammals filled by humus material (krotovina). Consistence is compact. Loamy sand. Slightly moist. The distinctness with next horizon is graduated, may be detected on the basis of the color and texture.

$\mathbf{P h}_{\mathbf{k}}(127-160 \mathrm{~cm})$ - the lower transition carbonate horizon. Grey $(2.5 \mathrm{Y} 6 / 1)$ with dark reddish gray (2.5YR 4/1) spots of the humus material. There are nodules of calcium carbonate on the depth 130-140 $\mathrm{cm}$. Loamy fine sand. Slightly moist. Consistence is compact. The distinctness with next horizon is abrupt, may be detected on the basis of the color and texture.

$\mathbf{P}_{\mathbf{k}}(160-200 \mathrm{~cm})$ - parent material. Grey-brown $(2.5 Y$ Y $5 / 2)$ large-grained sand. Moderately moist, friable. Vertical spots from humus material likely traces of decomposed plant roots width of $1 \mathrm{~cm}$, the height is $15-20 \mathrm{~cm}, 2-3$ spots on $10 \mathrm{~cm}$ in the horizontal direction.

The working definition of soil: sod-forest chornozem-like deep carbonate soil (Phaeozems Arenic).

Sampling polygon № 3. The vegetation of artificial pine forest included a total of 31 species of vascular plants. The tree stand are presented by Pinus sylvestris L.. The herbaceous layer are dominated by Calamagrostis epigeios (L.) Roth., Elymus repens (L.) Gould, Rubus caesius L.. The total projective cover of herbaceous species is 5-10\% (Gudym and Ganzha, 2016). For identification of plant communities, within which research was undertaken, we give it a syntaxonomy characteristic.

Class Robinietea Jurko ex Hadac et Sofron 1980

Ordo Chelidonio-Robinietalia Jurko ex Hadac et Sofron 1980

Union Balloto nigrae-Robinion Hadac et Sofron 1980 All. Calamagrostio epigeioris-Robinietum Smagaluk 2016

The herpetobiont invertebrates community included a total of 49 species representing 25 families and 12 orders and 7 classes from tree phylum (anneli$\mathrm{da}$, arthropods and molluses) at the sampling polygon (Zhukov et al., 2017). Taphoxenus gigas is included in the Red Book of Dnepropetrovsk region and Carabus (Pachystus) hungaricus (Fabricius, 1792) is included in the Red Book of Ukraine (Sumarokov et al., 2018). 


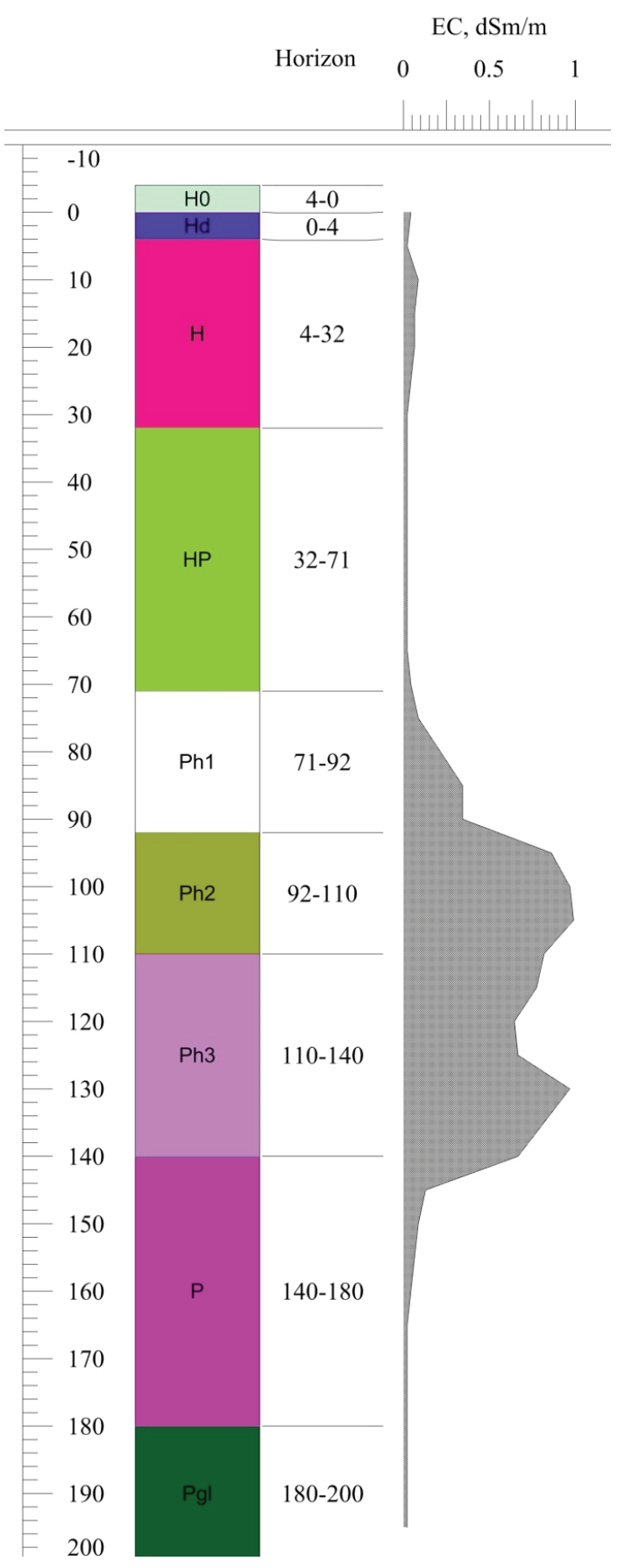

A
Horizon

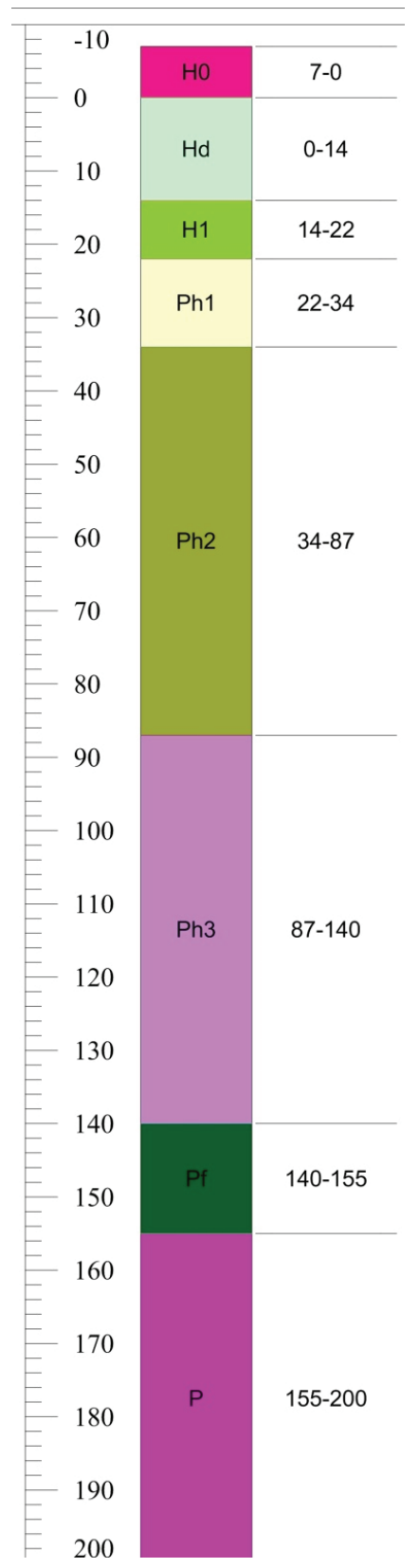

B

Fig. 4. The profile of sod-pine pseudofibres soil with shot profile (Ferric Arenosol Aridic) (A) and sod gley soil (Gleysols (Humic)) (B)

Legend: $\mathrm{A}-\mathrm{H}_{0}$ - organogenic, $\mathrm{H}_{\mathrm{d}}$ - upper soddy humus-accumulative, $\mathrm{H}_{1}$ - upper humus-accumulative, $\mathrm{Ph} 1$ - the first transition, Ph2 - the second transition, Ph3 - the third transition, Pf - pseudofibr horizon, $\mathrm{P}$ - parent material; $\mathrm{B}-\mathrm{H}_{0}$ - organogenic horizon, $\mathrm{H}_{\mathrm{d}}$ - upper soddy humus-accumulative horizon, $\mathrm{H}$ - upper humus-accumulative horizon, HP - transition horizon, Ph1 - the first lower transition horizon, Ph2 - the second lower transition horizon, $\mathrm{Ph} 3$ - the third lower transition horizon, $\mathrm{P}$ - parent material, $\mathrm{Pgl}$ - gley parent material

\section{Soil profile description}

The description was made in 24 June 2018. The soil section was located in the artificial pine forest within sand terrace of the Dnipro river (Fig. 4, A). The soil surface is relatively smooth. There is the forest litter consisted from pine needle, not decayed, with a depth of 5-7 cm, projective cover is $100 \%$. The litter has a layered structure, may be easily separated from the surface of the soil. The projective cover of the grass layer is $5-10 \%$. The parent material is alluvial sand. The groundwater level was not found. The depth of the roots of trees and shrubs up to $200 \mathrm{~cm}$. There soil cracks in humus layer but there are no in deeper layers. There are no the visible soil neoformation, carbonate 
debris, accumulation of salts. There are some traces of soil invertebrates activity. Evidence of the gleying were not found. Consistence is from loose to dense. The genetic profile type is humus differentiated.

$\mathbf{H}_{\mathbf{0}}(7-0 \mathrm{~cm})$ - organogenic, forest litter with projected cover $100 \%$, dry, compressed, well separated from the soil, has a layered structure.

$\mathbf{H}_{\mathbf{d}}(0-14 \mathrm{~cm})-$ upper soddy humus-accumulative. Brown-gray. Dry. Sandy loam. Layered. Consistence is floose. Soil is moderately or weakly bounded by root systems of herbaceous plants. Dust-grain structure. The cracks have a mainly horizontal direction. The distinctness with next horizon is abrupt, may be detected on the basis of the color, consistence and root content.

$\mathbf{H}_{1}(14-22 \mathrm{~cm})$ - upper humus-accumulative. Gray. Dry. Sandy loam. It is more dense than the previous horizon, but easily crumbles with a slight clicking. There are roots of herbaceous plants and shrubs. Structureless. The distinctness with next horizon is abrupt, may be detected on the basis of the color and consistence.

Ph1 $(22-34 \mathrm{~cm})$ - the first transition. Pale yellow with gray or dark gray spots. The traces of humous residuals of roots in a horizontal direction. Dry. Clay loam. Consistence is dense, almost condensed. There are no roots of living plants. Structureless. The distinctness with next horizon is abrupt and undulate, may be detected on the basis of the color.

Ph2 $(34-87 \mathrm{~cm})$ - the second transition. Pale yellow with gray or dark gray spots. The traces of humous large root residuals rounded with diameter $5-7 \mathrm{~cm}$. Dry. Clay loam. Consistence is dense, almost condensed. There are no roots of living plants. Structureless. The distinctness with next horizon is abrupt, may be detected on the basis of the color and consistence.

Ph3 $(87-140 \mathrm{~cm})$ - the third transition. Dark yellow with gray or dark gray spots. The traces of humous large root residuals rounded with diameter 5-7 $\mathrm{cm}$. Moderately moist. Sand. Consistence is friable. There are no roots of living plants. Structureless. The distinctness with next horizon is abrupt, may be detected on the basis of the higher margin of the pseudofibres.

$\operatorname{Pf}(140-155 \mathrm{~cm})-$ pseudofibr horizon. It consists of thin $(0.5-0.7 \mathrm{~cm})$ brown compacted layers (pseudofibres) which alternating with layers of yellow sand. Very moist. The distinctness with next horizon is abrupt, may be detected on the basis of the lower margin of the pseudofibres.

P $(155-200 \mathrm{~cm})$ - parent material. Light gray sand, very moist. Consistence is friable.

The working definition of soil: sod-pine pseudofibres soil with shot profile (Ferric Arenosol Aridic).

Sampling polygon № 4. The vegetation of meadow included a total of 19 species of vascular plants, among which are dominated by Calamagrostis epigeios (L.) Roth., Cirsium arvense (L.) Scop., and Elymus repens (L.) Gould. The total projective cover of herbaceous species is $90-100 \%$ (Gudym and Ganzha, 2016). For identification of plant communities, within which research was undertaken, we give it a syntaxonomy characteristic.

Syntaxonomy of the plant community:

\section{Class EPILOBIETEA ANGUSTIFOLII R.TX. ET PRSG 1950}

Ordo Epilobietalia angustifolii R.Tx. 1950

Union Epilobion angustifolii R.Tx. 1950

All. Calamagrostietum epigei Juraszek 1928

The herpetobiont invertebrates community included a total of 88 species representing 27 families and 10 orders and 6 classes from two phylum (arthropods and molluscs) at the sampling polygon (Zhukov et al., 2017). Carabus excellens is included in the Red Book of Dnepropetrovsk region and Carabus (s.str.) stscheglowi (Mannerheim, 1827) is included in the Red Book of Ukraine (Sumarokov et al., 2018).

\section{Soil profile description}

The description was made in 19 September 2018. The soil section was located in up the Orlova valley within the "Dnipro-Orylskiy" natural reserve (Fig. $4, \mathrm{~B})$. The vegetation is presented by meadow. The soil surface is relatively smooth. There is a litter cover with depth of 3-4 cm and with projective cover $90-100 \%$. The parent material is alluvial sand. The groundwater level is at a depth of $200 \mathrm{~cm}$. There are no the visible soil neoformation, carbonate debris, accumulation of salts. The soil consistency is dense or condence. The genetic type of the profile is humusgley. There was no an intense carbonate effervescence after dilute hydrochloric acid treatment.

$\mathbf{H}_{\mathbf{0}}(4-0 \mathrm{~cm})-$ organogenic horizon, litter with projected cover $70-90 \%$.

$\mathbf{H}_{\mathbf{d}}(0-4 \mathrm{~cm})$ - upper soddy humus-accumulative horizon. The quantity of roots is common. Dark grey. Dry. Light loam. Loose. The soil is fair aggregated, crumbly. The some aggregate are separately bonded by clusters of grass roots. The aggregate structure is granular-silty. Cracks are missing. The distinctness with next horizon is abrupt, may be detected on the basis of the clear roots content decrease and changes of the color and aggregate structure.

H $(4-32 \mathrm{~cm})$ - upper humus-accumulative horizon. Dark grey. Dense. Moist. Light loam. Roots are 
absent. Cracks are missing. The distinctness with next horizon is gradual, may be detected on the basis of the color and cracks.

HP $(32-71 \mathrm{~cm})$ - transition horizon. Light grey, condensed. Moderately moist. Light loam. The verticals cracks having a width of $0.2 \mathrm{~cm}$ create 15-20 $\mathrm{cm}$ width pedes. Roots are absent. Roots are absent. Cracks are missing. The distinctness with next horizon is gradual, may be detected on the basis of the color and cracks.

Ph1 $(71-92 \mathrm{~cm})$ - the first lower transition horizon. Light gray. Moderately moist. Consistence is compact. Light loam, there are no cracks. Light yellow spots of irregular shape with a diameter of 15-20 $\mathrm{cm}$ are presented. The distinctness with next horizon is gradual, may be detected on the basis of the color.

Ph2 (92-110 cm) - the second lower transition horizon. Light yellow with vertical humus spots. Consistence is compact. Light loam. Moist. The distinctness with next horizon is gradual, may be detected on the basis of the color, unclear.

Ph3 (110-140 cm) - the third lower transition horizon. Light yellow, lighter than the previous one, the marble from the enclosures of the humus spots. Light loam. Moist. The distinctness with next horizon is clear, may be detected on the basis of the color and texture.

P $(140-180 \mathrm{~cm})$ - parent material. Blue-gray clay sand. Very moist. Consistence is soft.

Pgl $(180-200 \mathrm{~cm})$ - gley parent material. Dark blue-gray sand with reddish spots. Consistence is soft.

The working definition of soil: sod gley soil (Gleysols (Humic)).

Sampling polygon № 25. The vegetation of poplar-willow forests (habitat type according EUNIS G1.1112 Eastern European poplar-willow forests) included a total of 38 species of vascular plants. The tree stand are dominated by Populus alba L. та Ulmus laevis Pall.. The shrub layer are dominated by Acer tataricum L., Crataegus rhipidophylla Gand., and Sambucus nigra L., the herbaceous layer are dominated by Anthriscus cerefolium (L.) Hoffm., Galium aparine L. та Stellaria media (L.) Vill. The total projective cover of herbaceous species is $25-30 \%$. For identification of plant communities, within which research was undertaken, we give it a syntaxonomy characteristic.

Class Salicetea purpureae Moor 1958

Ordo Salicetalia purpureae Moor 1958

Union Salicion albae R.Tx. 1955

All. Populetum albae Br.-B1.1931
The soil invertebrates community included a total of 66 species representing 27 families and 10 orders and 6 classes from tree phylum (annelida, arthropods and molluses) at the sampling polygon. Carabus excellens is included in the Red Book of Dnepropetrovsk region and Carabus (s.str.) stscheglowi (Mannerheim, 1827 ) is included in the Red Book of Ukraine (Sumarokov et al., 2018).

\section{Soil profile description}

The description was made in 5 May 2018 (additionally - 2 June) (Fig. 5, A). The poplar-willow forests in the floodplain of the inflow of Protich river (margin of the sand terrace of Dnipro river valley). The soil surface is relatively smooth. There is the litter consisted from leaves, not decayed, with a depth of 5-6 cm, projective cover is $90-100 \%$. The projective cover of the grass layer is $25-30 \%$. The parent material is alluvial sand. The groundwater level was $90 \mathrm{~cm} 5$ May, 2 June the groundwater level was $122 \mathrm{~cm}$. There are some traces of soil invertebrates activities, which are mixing horizons not exercise significant influence. There are no the visible soil neoformation, carbonate debris, accumulation of salts. Consistence is from friable to dense. The genetic profile type is humus differentiated. An intense carbonate effervescence after dilute hydrochloric acid treatment was occurred from the surface.

$\mathrm{H}_{0}(6-0 \mathrm{~cm})-$ organogenic, forest litter with projected cover $90-100 \%$.

Hdk (0-7 cm) - upper soddy carbonate humusaccumulative horizon. Yellow-red (10YR 4/2), interspersed with sand particles, tightly intertwined by roots of herbaceous plants. Dry. Clay sand. The structure is grain-dust. Consistence is friable. There are no cracks. The distinctness with next horizon is clear, may be detected on the basis of the color and consistence.

$\mathbf{H}_{\mathbf{k}}(7-35 \mathrm{~cm})$ - humus-accumulative carbonate horizon. Blue-gray (5B 5/1) interspersed with sand particles. Consistence is friable, slightly moist. Clay sand. There are some roots of shrubs. There are no cracks. Structureless. The distinctness with next horizon is gradual, may be detected on the basis of the wetness and texture.

$\mathbf{H p}_{\mathbf{k}}(35-58 \mathrm{~cm})$ - the upper transition carbonate horizon. Black (2.5Y 2.5/1). Consistence is friable, moist. Viscous, tacky. There are roots of shrubs. There are no cracks. Structureless. Consistence is dense. The distinctness with next horizon is gradual, may be detected on the basis of the color.

$\mathbf{H P}_{\mathbf{k}}(58-80 \mathrm{~cm})$ - the transition carbonate horizon. Gray (10YR 6/1) interspersed with light-gray (2.5Y 7/1) sand particles. Sandy loam. Moderate- 


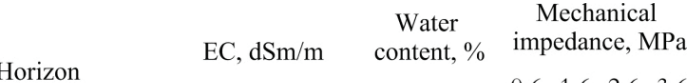

$\begin{array}{llllllllllll}0 & 0.5 & 1 & 1.5 & 228 & 30 & 32 & 34^{0.6} & 1.6 & 2.6 & 3.6\end{array}$

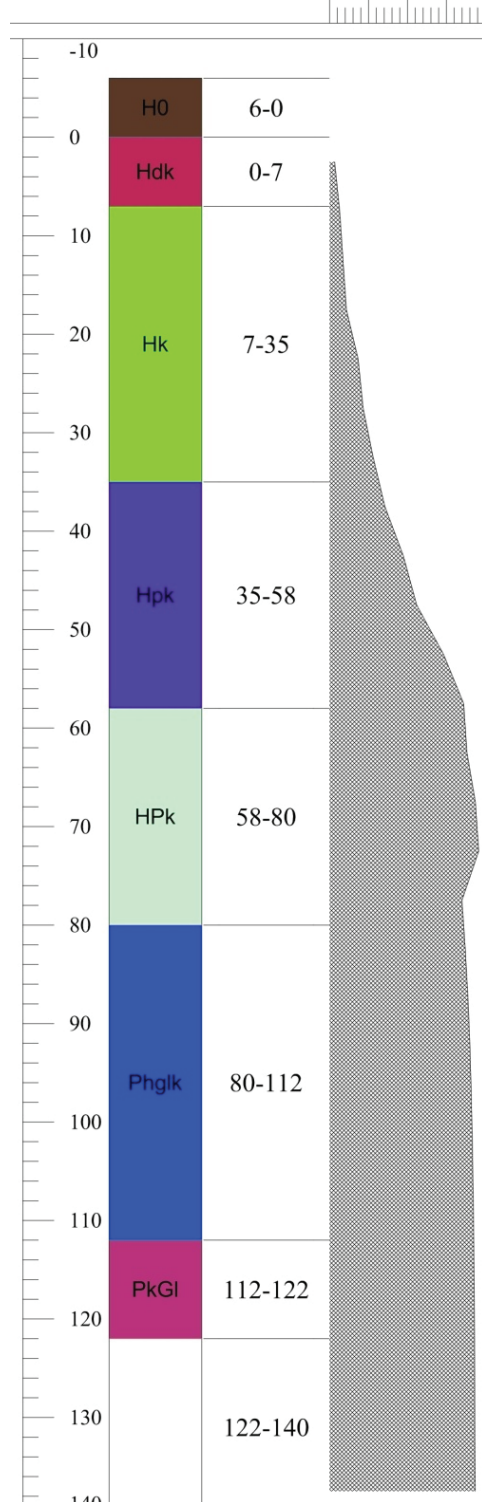

A

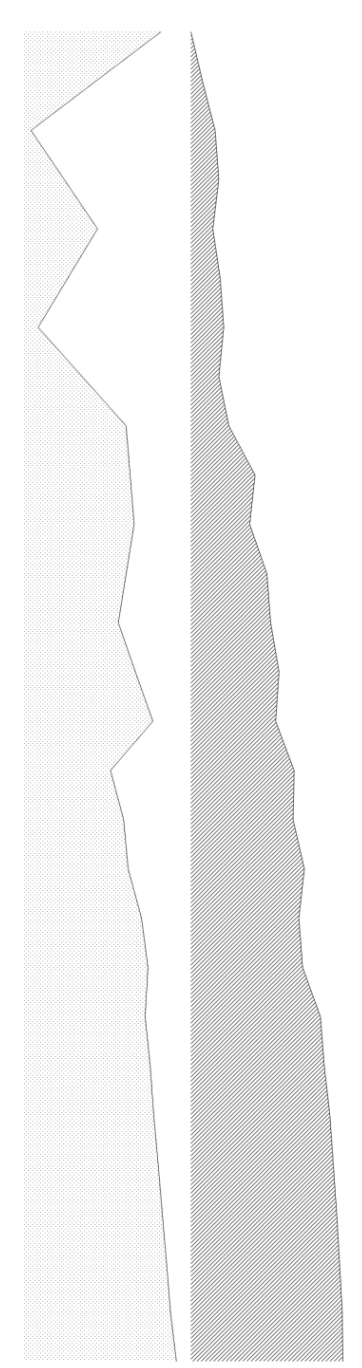

Horizon

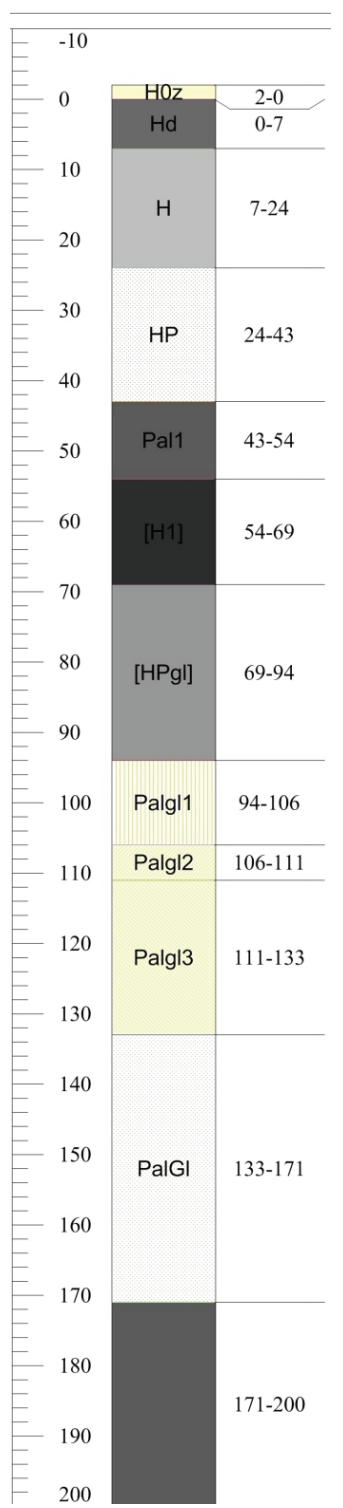

$\mathrm{B}$

Fig. 5. The profile of alluvial meadow and forest deep loamy soil (Mollic Gleyic Fluvisol (Calcaric)) (A) and alluvial sod forest layered normal gley soil (Umbric Gleyic Fluvisol) (B)

Legend: $\mathrm{A}-\mathrm{H}_{0}$ - organogenic, $\mathrm{Hdk}$ - upper soddy carbonate humus-accumulative horizon, $\mathrm{H}_{\mathrm{k}}$ - humus-accumulative carbonate horizon, $\mathrm{Hp}_{\mathrm{k}}$ - the upper transition carbonate horizon, $\mathrm{HP}_{\mathrm{k}}$ - the transition carbonate horizon, Phglk - the transition carbonate gleysolic horizon, $\mathrm{PkGl}$ - carbonate gleysolic parent material; $\mathrm{B}-\mathrm{H}_{0 \mathrm{z}}$ - organogenic, $\mathrm{H}_{\mathrm{d}}$ - upper soddy humus-accumulative horizon, $\mathrm{H}$ - humus-accumulative, $\mathrm{HP}$ - transition horizon, $\mathrm{P}_{\mathrm{al}} 1$ - alluvial horizon, [H1] - the first buried humus-accumulative horizon, [HPgl] - the buried gleysolic humus-accumulative horizon, $\mathrm{P}_{\text {agl }} 1$ - the fist alluvial gleysolic horizon, $\mathrm{P}_{\text {agg }} 2-$ the second alluvial gleysolic horizon, $\mathrm{P}_{\text {algl }} 3-$ the third alluvial gleysolic horizon, $\mathrm{P}_{\mathrm{alGl}}-$ alluvial gleysolic parent material

ly moist. Densed. There are no roots of shrubs and cracks. The distinctness with next horizon is abrupt, may be detected on the basis of the consistence.

Phglk $(80-112 \mathrm{~cm})$ - the transition carbonate gleysolic horizon. Blue-gray (10B 5/1), gradually brightens with the depth, moist. A dense, almost merged, sticky and plastic. Sandy loam, there are no cracks. The distinctness with next horizon is abrupt, may be detected on the basis of the color and texture.

PkGI (112-122 cм) - carbonate gleysolic parent material. Yellow (5Y 6/2) sand. Wet. Densed, consists of large lumps of sand that disintegrate when pressed. Bordered by subsoil waters.

The working definition of soil: alluvial meadow and forest deep loamy soil (Mollic Gleyic Fluvisol (Calcaric). 
The alluvial sod soils are formed in riverine floodplain within the natural reserve "DniproOrilsky" on layered sandy alluvium. There are four subtypes in type of alluvial soil: primitive sod, sod underdeveloped, sod short profile and sod valid (Nakonechny, Pozniak, 2011). The weak participation of groundwater water in water regime of profile through a limited lifting height of capillary water in the sands is peculiarity of this soil type. The signs of gleization are poorly expressed or absent. The short profile soil are the most common types (Manyuk, 2005). Alluvial sod soils are formed at the highest parts of the floodplain. Profile of soils consisting of three genetic horizons - humus-accumulative $(\mathrm{H})$, transition $(\mathrm{Ph})$ and parent material $(\mathrm{P})$. Humus horizon is gray, wet, compacted (Nakonechny, 2016). Sampling polygon № 26. The vegetation of flooded oak forest included a total of 60 species of vascular plants (Zhukov et al., 2017). The tree stand are dominated by Quercus robur та Ulmus laevis. The shrub layer are dominated by Rubus caesius та Amorpha fruticosa. The total projective cover of herbaceous species is $30-40 \%$. For identification of plant communities, within which research was undertaken, we give it a syntaxonomy characteristic.

Class Alno glutinosae-Populetea albae P. Fukarek et Fabijanić 1968 (або Carpino-Fagetea Passarge in Passarge et G. Hofmann 1968)

Ordo Alno-Fraxinetalia excelsioris Passarge et G. Hofmann 1968

Union Alnion incanae Pawłowski, Sokołowski et Wallisch 1928

Subunion Ulmenion minoris Oberdorfer 1953 дубово-в'язові заплавні ліси

The soil invertebrates community included a total of 34 species with a total abundance of $178.4 \pm$ 26.9 ind. $/ \mathrm{m}^{2}$ (Zhukov et al., 2018). The earthworm is a dominant group, which constitute $38.8 \%$ of the total community abundance. Earthworms are presented by four ecological types: litter dwelling Dendrobaena octaedra, two species of the endegeic Aporrectodea trapezoides and Aporrectodea rosea and one species of the anecic Octodrilus transpadanus.

\section{Soil profile description}

The description was made in 3 October 2017 (Fig. 5, B). The oak forest in the floodplain of the Dnipro river. The soil surface is relatively smooth. There is the litter consisted from leaves, not decayed, with a depth of $1.5-2 \mathrm{~cm}$, projective cover is $30-40 \%$ digging extensively by boar. The parent material is alluvial sand. The groundwater level was $171 \mathrm{~cm}$. There are no the visible soil neoformation, carbonate debris, accumulation of salts. Consistence is dense. The genetic profile type is humus differentiated. There is no a carbonate effervescence after dilute hydrochloric acid treatment.

$\mathbf{H}_{\mathbf{0 z}}(2-0 \mathrm{~cm})-$ organogenic, forest litter with projected cover $30-40 \%$, digging extensively by boar.

$\mathbf{H}_{\mathbf{d}}(0-7 \mathrm{~cm})$ - upper soddy humus-accumulative horizon. Light-gray. Dry. Clay sand. Consistence is friable, tightly intertwined by roots of herbaceous plants. Structureless. The distinctness with next horizon is abrupt, may be detected on the basis of the consistence.

H $(7-24 \mathrm{~cm})$ - humus-accumulative. Light-gray. Slightly moist. Clay sand. Consistence is condensed, tightly intertwined by roots of herbaceous plants. Structureless. The distinctness with next horizon is graduated, may be detected on the basis of the consistence.

HP $(24-43 \mathrm{~cm})$ - transition horizon. Yellowgray. Moderately moist. Clay sand. Structureless. Consistence is condensed. There are some roots of shrubs and trees. The distinctness with next horizon is abrupt, may be detected on the basis of the color.

$\mathbf{P}_{\text {al }} \mathbf{1}(43-54 \mathrm{~cm})$ - alluvial horizon. Light-gray with rusty spots, which increase with depth. Sand. Slightly moist, structureless. There are occasionally vertical humus smudges. The distinctness with next horizon is diffuse, may be detected on the basis of the color.

[H1] $(54-69 \mathrm{~cm})$ - the first buried humus-accumulative horizon, structureless. Dark-gray. There are some roots. There are no cracks. Sand. Condensed. Slightly moist. There are occasionally vertical humus smudges. The distinctness with next horizon is graduated, may be detected on the basis of the color.

[HPgl] $(69-94 \mathrm{~cm})$ - the buried gleysolic humus-accumulative horizon. Dark-gray. ark red spots irregularly shaped $3-5 \mathrm{~cm}$ in diameter. There are some roots. There are no cracks. Sand. Condensed. Moderately moist. There are occasionally vertical humus smudges. The distinctness with next horizon is abrupt, may be detected on the basis of the color.

$\mathbf{P}_{\text {algl }} \mathbf{1}(94-106 \mathrm{~cm})$ - the fist alluvial gleysolic horizon. Yellow-gray. Loose sand. Vertical humusovani smudges. The distinctness with next horizon is graduated, may be detected on the basis of the color.

$\mathbf{P}_{\text {algl }} \mathbf{2}(106-111 \mathrm{~cm})$ - the second alluvial gleysolic horizon. Gray. Loose sand. Moderately moist. The distinctness with next horizon is graduated, may be detected on the basis of the color.

$\mathbf{P}_{\text {algl }} \mathbf{3}(111-133 \mathrm{~cm})$ - the third alluvial gleysolic horizon. Red-rusty. Loose sand. Moderately moist. 
The distinctness with next horizon is graduated, may be detected on the basis of the color.

$\mathbf{P}_{\text {alGI }}(133-171 \mathrm{~cm})$ - alluvial gleysolic parent material. Sand. Moderately moist. Dark-blue-gray, loose.

The working definition of soil: alluvial sod forest layered normal gley soil (Umbric Gleyic Fluvisol).

Floodplains are among the most young and dynamic landscape elements. They were formed in the Holocene and continue to develop rapidly (Parkhomenko, 2015). Floodplain ecosystems are complex natural systems that characterized by a large spatial variability (Reddy, Patrick, 1993; Stolt, 2001; Rinklebe, Langer, 2006). The soils in the floodplain habitats are affected by erosion and the effects of sedimentation and transformation and translocation of substances which generally has the permanent effect, which forms veins and layers of sand or clay deposits, and varying degrees of accumulation of humus (Wälder et al., 2008). The floodplain soils are significantly affected by the underlying processes of rocks and parent materials, variability of standing groundwater, past and current velocity of water flow in the river, relief positions, approaching the river or dam and anthropogenic impacts (Wälder et al., 2008). Floodplain soils are seen as complex and polygenetical and polychronos formation, reflecting the long stages and litho-geomorphological paedogenesis and geological structure of river valleys (Mikhailyuk, 2001).

Floodplain of the Dnipro river is formed by furcation type. The genetic zones of the modern floodplain are formed due channel furcation, superimposed on genetic areas associated with the degree of remoteness from the mainstream, ie attenuation of alluvial tension. The floodplain relief is considered as segment systems within each of which formed riverine, floodplain and central plant conditions (Mirkin, 1974). The area of the floodplain is periodically covered by floodwater, after which the recession on soil surface is silt, which determines the morphological characteristics, properties and fertility of alluvial soils and lithology. The alluvial soils form a complex mosaic structure of soil cover due to unequal treatment of flood waters in different parts of the floodplain (Manyuk, 2005).

\section{Conclusions}

1. The biogeocenotic approach is the chain that connects the landscape structure, the diversity of soil cover, and diversities of the plant and animal communities. The functional, spatial and temporal properties of ecosystems in landscape context can be expressed by catena. Within the natural reserve
«Dnipro-Orilsky» catena covers of the floodplain and sand terraces biogeocoenoses.

2. The biogeocoenosis concept is a basis for integration of the pedocatena, phytocatena and zoocatena. Catena approach is the framework for a monitoring system landscape diversity both at the level of individual component biogeocoenosis (edaphotop, phytocenosis, and zoocenosis) and biogeocoenosis level in terms of its horizontal and vertical structure and at the landscape level as a whole interconnected system.

3. The traditional idea of catena as a set of eluvial, transit and accumulative positions in a complex and diverse landscape is not able to cover the mostimportant environmental gradients modes. The complexity of the landscape is due to relief diversity and the effects of anthropogenic transformation biogeocenotic cover. Catena therefore can be seen as a multilevel hierarchical system of the biogeocenotic polygons needed to consider the diversity of physiographic conditions and anthropogenic gradients.

\section{References}

Gudym, N. G. \& Ganzha, D. S. (2016). Ecomorph structure of phytocenosis on the arena of the Dnipro river (within 'Dnipro-Orelsky' natural reserve) [Ekomorfichna struktura fitotsenoziv na areni r. Dnipro (v mezhakh pryrodnoho zapovidnyku 'Dniprovsko-Orilskyi')], Issues of Steppepe Forestry and Forest Reclamation of Soils [Pytannia steppeovoho lisoznavstva ta lisovoi rekultyvatsii zemel], 45, pp. 40-48. (in Ukrainian).

Gudym, N. G. (2015). Pelobates fuscus seasonal population dynamics of r. Dnipro arena (within DniproOrelsky Natural Reserve) [Sezonna dynamika chyselnosti Pelobates fuscus na areni r. Dnipro (v mezhakh pryrodnoho zapovidnyku 'DniprovskoOrilskyi')], Problems of bioindications and ecology [Pytannia bioindykatsii ta ekolohii], 20(2), pp. 130-141. URL: http://nbuv.gov.ua/ UJRN/pbte_2015_20_2_13. (in Ukrainian).

Karpachevsky, L. O. (2005). Ecological soil science. Moscow, Geos (in Russian).

Manyuk V. V. (2005). Structure, typology, dynamics and restoring oak Dnyprovsko-Orylsky Nature Reserve: Dis. candidate. Biol. Sciences: 03.00.16. Dnipropetrovsk, 373 p. (in Ukrainian).

Mikhailyuk V.I. (2001). The soils of river valleys northwest of the Black Sea ecology, genesis, taxonomy, properties, problems of use. Odessa: Astroprint, $340 \mathrm{p}$.

Mirkin B.M. (1974). Laws of development of vegetation of floodplains, Nauka, $144 \mathrm{p}$.

Nakonechny J. (2016). Soil upper valley of the river Western Bug. Scientific notes of Ternopil National 
Pedagogical University named Hnatyuk. Avg. Geography, 2 (41), 42-50.

Nakonechny Yu., Pozniak S.P. (2011). River floodplain soils of the Western Bug. Lviv: Ivan Franko LNU, $220 \mathrm{p}$.

Parkhomenko O. G. (2015). Holocene floodplain paedogenesis the Middle Dnipro // Scientific Journal of MP NEA Dragomanova. Seriya 4. Geography and modernity, 19 (33), 63-73.

Pennisi B.V., van Iersel, M. (2002). 3 ways to measure medium EC. GMPro, 22(1), 46-48.

Reddy K.R., Patrick, W.H. (1993). Wetland soils - opportunities and challenges. Soil Sci Soc Am J., 57, $1145-1147$.

Rinklebe J., Langer, U. (2006). Microbial diversity in three floodplain soils at the Elbe River (Germany). Soil Biol Biochem., 38, 2144-2151.

Rosanov B. G. (2004). Morphology of the soils. Moscow: Academic project, $432 \mathrm{p}$.

Scoggins H. L., van Iersel M. W. (2006). In situ probes for measurement of EC of soilless substrates: effects of temperature and substrate moisture content. HortScience, 41, 210-214.

Skvortsova E. B., Abrosimov K.N., Romanenko K.A. (2015). Profile changes of the micromorphometric indicators of the pores in the zonal soils of the European part of Russia. Bulletin of V.V. Dokuchaev Soil Science Institute. 78, 42-58.

Smagin A. V. (2012). Theory and practice of designing soil. Moscow: Moscow University Press, $542 \mathrm{p}$.

Stolt M.H., Genthner M.H., Daniels W.L., Groover V.A. (2001). Spatial variability in Palustrine Wetlands. Soil Sci Soc Am J. 65, 527-535.

Sumarokov, O.M., Kunah, O.M. \& Zhukov O.V. (2018). Soil-dwelling invertebrates in DniprovskoOrelsky Nature Reserve Dataset ID \#3976. In: UkrBIN: Ukrainian Biodiversity Information Network [public project \& web application]. UkrBIN, Database on Biodiversity Information. Available from: http://www.ukrbin.com Accessed: Date [e.g. September 14, 2018]

Vadyunina A.F., Korchagina Z. A. (1986). Methods of studying the physical properties of soil. Agropromizdat, $416 \mathrm{p}$.

Wälder K., Wälder O., Rinklebe J., Menz J. (2008). Estimation of soil properties with geostatistical methods in floodplains. Archives of Agronomy and Soil Science. 54 (3), 275-295.

Zhukov, A., Gadorozhnaya, G. (2016). Spatial heterogeneity of mechanical impedance of a typical chernozem: the ecological approach. Ekológia (Bratislava). 35, 263-278. DOI: https://doi.org/10.1515/ eko-2016-0021

Zhukov, A.V., Zadorozhnaya, G.A. 2016. Spatio-temporal dynamics of the penetration resistance of recultivated soils formed after open cast mining.
Visnyk of Dnipropetrovsk University. Biology, ecology. 24(2), 324-331. DOI: 10.15421/011642

Zhukov O., Kunah O., Dubinina Y., \& Novikova V. (2018). The role of edaphic and vegetation factors in structuring beta diversity of the soil macrofauna community of the Dnipro river arena terrace. Ekológia (Bratislava), 37, 3, 301-327. DOI:10.2478/eko-2018-0023

Zhukov O., Kunah O., Dubinina Y., \& Novikova V. (2018). The role of edaphic, vegetational and spatial factors in structuring soil animal communities in a floodplain forest of the Dnipro river. Folia Oecologica, 45, 8-23. doi: 10.2478/foecol-2018-0002

Zhukov, O.V., Pisarenko, P.V., Kunah, O.M., \& Dichenko, O.J. (2015). Role of landscape diversity in dynamics of abundance of sugar beet pests population in Poltava region. Visnyk of Dnipropetrovsk University. Biology, ecology, 23, 1, 21-27. DOI: https://doi.org/10.15421/011504

Zhukov, A. V., Gudym, N. G., \& Dubinina, Y. Y. (2017). Soil mesofauna of the meadow community in the floodplain of the Protich river (the Nature Reserve "Dnipro-Orilsky"). The Kharkov Entomol. Soc. Gaz., XXV (2), 22-39.

Zhukov, A.V., Andrusevich, K.V., Lapko, K. V., \& Sirotina, V. O. (2015). Geostatistical estimation of soil aggregate structure as a composite variable. Biological Bulletin, 3, 101-121. http://dx.doi. org/10.7905/bbmspu.v5i3.989

Zhukov, A.V., Kunah, O.N., Novikova, V.A., \& Ganzha, D.S. (2016). Phytoindication estimation of soil mesopedobionts communities catena and their ecomorphic organization. Biological Bulletin of Bogdan Chmelnitskiy Melitopol State Pedagogical University, 6 (3), 91-117. DOI: http://dx.doi.org/10.15421/201676

Zhukov, O.V. (2015). Influence of usual and dual wheels on soil penetration resistance: the GIS-approach. Biological Bulletin Of Bogdan Chmelnitskiy Melitopol State Pedagogical University. 3, 73-100. DOI: $10.7905 /$ bbmspu.v5i3.988

Zhukov, O.V., \& Gubanova, N.L. (2015). Dynamic stability of communities of amphibians in short-termfloodedforest ecosystems. Visnyk of Dnipropetrovsk University. Biology, ecology, 23 (2), 161-171. doi:10.15421/011523

Zhukov, O.V., Kunah, O. M., Dubinina, Y.Y., \& Ganzha, D. S. (2017). Diversity and phytoindication ability of plant community. Ukrainian Journal of Ecology. 7(4), 81-99. doi:10.15421/2017_90

Zhukov, O.V., Kunah, O.N., \& Novikova, V.A. (2016). The functional organisation of the mesopedobionts community of sod pinewood soils on arena of the river Dnepr. Visnyk of Dnipropetrovsk University. Biology, ecology. 24(1), 26-39. doi:10.15421/011604 